Bond University ePublications@bond

Sports Law eJournal

Faculty of Law

October 2008

\title{
The CAS An Arbitral Institution with its Seat in Switzerland
}

Dr. Meinrad Vetter

mvetter@vischer.com

Follow this and additional works at: http://epublications.bond.edu.au/slej

\section{Recommended Citation}

Dr. Meinrad Vetter. (2008) "The CAS An Arbitral Institution with its Seat in Switzerland" „, .

http://epublications.bond.edu.au/slej/9

This Journal Article is brought to you by the Faculty of Law at ePublications@bond. It has been accepted for inclusion in Sports Law eJournal by an authorized administrator of ePublications@bond. For more information, please contact Bond University's Repository Coordinator. 


\title{
The CAS An Arbitral Institution with its Seat in Switzerland
}

\begin{abstract}
The Court of Arbitration for Sport (the CAS) has become a very successful international arbitral body. The CAS has its seat in Switzerland - arbitration before the CAS is based on Swiss law. In this article, Meinrad Vetter presents an overview of Swiss law governing CAS cases, including the rules of procedure on appeals from the CAS to the Swiss Supreme Court.
\end{abstract}

Keywords

The CAS, international arbitration, sport, rules of procedure, Swiss Supreme Court 


\title{
THE CAS - AN ARBITRAL INSTITUTION WITH ITS SEAT IN SWITZERLAND
}

\author{
DR IUR MEINRAD VETTER*
}

\section{INTRODUCTION}

Since its creation in 1984, the Court of Arbitration for Sport (CAS) ${ }^{1}$ has been established as one of the most important dispute resolution bodies for sport disputes worldwide. Advantages like confidentiality, specialisation of the arbitrators, flexibility and simplicity of the procedure, speed, costs and international effectiveness of the arbitral award are the main reasons that this arbitral institution occupies an important place within the international sports community and the world of international arbitration. ${ }^{2}$

Because the CAS has its seat in Lausanne, Switzerland, the arbitration before the CAS is always based on Swiss law. That is why this article presents the relevant Swiss law for CAS cases. After a short overview of the organisation and the scope of the CAS, this article gives non-Swiss lawyers in particular an overview of Chapter 12 of the Swiss International Private Law Act of 18 December 1987 $(\text { PILA })^{3}$ as the lex arbitri of most CAS cases. This overview focuses on PILA's procedural provisions. The procedure for appeals against CAS awards to the Swiss Supreme Court has a special focus.

\section{ORGANISATION AND SCOPE OF THE CAS}

Regardless of the notation 'court', the CAS is a private arbitral institution and not a state court. ${ }^{4}$ The court office is in Lausanne, Switzerland. The CAS also has two permanent decentralised offices in Sydney and in New York. ${ }^{5}$

The CAS was founded on 30 June 1984 by the International Olympic Committee (IOC). With the CAS as arbitral institution, the IOC wanted to create 'a specialized authority capable of settling international disputes and offering a flexible, quick and inexpensive procedure'. ${ }^{6}$ Since 1994, the International Council of Arbitration for Sport (ICAS) instead of the IOC has been running and

\footnotetext{
* Attorney at law in Switzerland. Email: meinrad.vetter@alumni.unisg.ch.

1 In French: Tribunal Arbitral du Sport (TAS).

2 Matthieu Reeb, 'The Role and Functions of the Court of Arbitration for Sport (CAS)' in Ian S Blackshaw, Robert CR Siekmann and Janwillem Soek (ed), The Court of Arbitration for Sport 1984 - 2004 (2006) 31, 38-9.

3 Swiss Federal Act on International Private Law (1989) <http://www.admin.ch/ch/d/sr/2/291.de.pdf $>$ at 22 October 2008. An English translation of Chapter 12 PILA is available on the CAS website $<$ http://www.tas-cas.org/en/arbitrage.asp/4-3-292-1023-4-1-1/5-0-1023-3-0-0/> at 22 October 2008.

4 'Arbitration is a process used by the agreement of the parties to resolve disputes. In arbitrations, disputes are resolved, with binding effect, by a person or persons acting in a judicial manner in private, rather than by a national court of law that would have jurisdiction but for the agreement of the parties to exclude it. The decision of the arbitral tribunal is usually called award.' (Butterworths, Halsbury's Laws of England, vol 2(3) (4th ed, 2003) Arbitration '1. The Law of Arbitration' [1]).

5 Matthieu Reeb, 'The Court of Arbitration for Sport: History and Operation' in Matthieu Reeb (ed), Digest of CAS Awards III (2001 - 2003) (2004) xxvii, xxxiii.

6 Reeb, above n 2, [32].
} 
financing the CAS.7 The organisation and the arbitration procedures of the CAS are governed in the Code of Sports-related Arbitration (the Code) ${ }^{8}$

According to R27(1) Code, the CAS has jurisdiction if the parties agreed on any of the following conditions:

- arbitration clause inserted in a contract or regulations or of a later arbitration agreement (ordinary arbitration proceedings), or

- appeal against a decision rendered by a federation, association or sports-related body where the statutes or regulations of such bodies, or a specific agreement provides for an appeal to the CAS (appeal arbitration proceedings).

Furthermore, the disputes may involve matters of principle relating to sport or matters of pecuniary or other interests brought into play in the practice or the development of sport and, generally speaking, any activity related or connected to sport (R27(2) Code).

Similar to the above-mentioned distinction in ordinary arbitration proceedings and appeal arbitration proceedings, the CAS is separated into the Ordinary Arbitration Division and the Appeals Arbitration Division (S20 Code). Additionally to the General Provisions (R27-R37 Code), special provisions apply for the Ordinary Arbitration Procedure (R38-R46 Code) as well as for the Appeal Arbitration Procedure (R47-R59 Code). Furthermore, the CAS forms special ad hoc divisions for major sporting events, primarily the Olympic Games. However, other main sporting events, like the Commonwealth Games or the European Football Championships, make use of CAS ad hoc divisions. ${ }^{9}$ For ad hoc divisions special arbitration rules apply. ${ }^{10}$

If an arbitration clause is concluded which determines that the CAS is the relevant arbitral institution, the parties are compelled to go to the CAS for dispute resolution. In this case, the jurisdiction of the CAS is exclusive. ${ }^{11}$ Litigation before a state court or arbitration before a different arbitral tribunal is not possible.

These days, all Olympic International Federation and several non-Olympic federations recognise the CAS as the only and exclusive arbitral institution. ${ }^{12}$ The arbitration clauses in their statutes and contracts explicitly refer to the CAS. ${ }^{13}$ Hence, the CAS is the decisive dispute resolution body for many Australian federations and their athletes. ${ }^{14}$

7 Ibid 34. For the history of the CAS see Reeb, above n 5, [xxxiv-xxxi].

8 Code of Sports-related Arbitration $<$ http://www.tascas.org/d2wfiles/document/281/5048/0/3.1\%20CodeEngnov2004.pdf> at 22 October 2008.

9 Reeb, above n 5, [xxxiv]. For the fundamental workings of the CAS ad hoc Division at the 2000 Summer Olympic Games in Sydney see Gabrielle Kaufmann-Kohler, Arbitration at the Olympics (2001) 41 - 50.

10 See eg Arbitration Rules of the Olympic Games <http://www.tascas.org/d2wfiles/document/422/5048/0/rules\%20English\%20(2008.07.04).pdf $>22$ October 2008 and Arbitration Rules for the UEFA 2008 Final Round <http://www.tascas.org/d2wfiles/document/1453/5048/0/RulesEURO2008.pdf > at 22 October 2008.

11 Andrea Pinna, 'The Trials and Tribulations of the Court of Arbitration for Sport. Contribution to the Study of the Arbitration of Disputes Concerning Disciplinary Sanctions' in Blackshaw, Siekmann and Soek (ed), above $n$ 2, [386, 387].

12 Matthieu Reeb, above n 5, [xxxiv].

13 See the CAS standard clauses for the ordinary arbitration procedure $<$ http://www.tascas.org/en/arbitrage.asp/4-3-278-1021-4-1-1/5-0-1021-3-0-0/> at 22 October 2008.

14 See eg Nicolas D'Arcy v Australian Olympic Committee (CAS 2008/A/1574) <http://www.tascas.org/d2wfiles/document/1460/5048/0/award\%201574\%20internet.pdf > at 22 October 2008; Australian Sports Anti-Doping Authority v Nathan O'Neill (CAS A1/2008) $<$ http://www.tas-cas.org/d2wfiles/document/1447/5048/0/award\%20O'Neill\%202008.06.13.pdf> at 14 July 2008; Australian Sports Anti-Doping Authority v Belinda van Tienen (CAS A3/2007) 
The New South Wales' Court of Appeal confirmed this exclusivity of the CAS in Raguz $v$ Sullivan. In this case, the judoka Angela Raguz was nominated as the Australian representative for the Sydney Olympic Games 2000. Rebecca Sullivan, another judoka in the same weight category, challenged this - before the internal tribunal of the Judo Federation. Raguz won. Sullivan appealed to the CAS. All three arbitrators were Australians. They found in Rebecca Sullivan's favour. Angela Raguz appealed to the NSW Court of Appeal using the NSW Commercial Arbitration Act 1984. Although both parties were Australian residents and the CAS arbitral hearing took place in Sydney, the New South Wales' Court of Appeal declined to review the CAS award owing to lack of jurisdiction. ${ }^{15}$ The Court held that the Selection Agreements, which both Raguz and Sullivan signed, contained an 'exclusion agreement' as defined by s 40 of the Commercial Arbitration Act and that the NSW Supreme Court therefore did not have jurisdiction to grant leave to appeal under s 38(4) of the Act. The agreed juridical 'seat' or place of arbitration was Switzerland. As well as stating that the CAS decision would itself be 'final and binding on the parties', the agreement said that 'neither party will institute or maintain proceedings in any court or tribunal other than the said court.' This demonstrated a clear intention to oust the NSW Court's appellate jurisdiction. ${ }^{16}$

\section{CHAPTER 12 PILA}

\section{A The seat of the CAS arbitral tribunal is always in Lausanne}

The procedural law of the arbitration is called lex arbitri. ${ }^{17}$ This law governs the arbitration proceedings, namely the conduct of the arbitration and the supervisory power of the court. ${ }^{18}$ It is to distinguish from the substantive or proper law (the applicable law to the merits) ${ }^{19}$ as well as from the procedural rules of the arbitration (in CAS arbitrations the Code). The lex arbitri is mostly the law of the place or seat of the arbitral tribunal. ${ }^{20}$

According to article R28 of the Code, '[t]he seat of the CAS and of each Arbitration Panel ('Panel') is in Lausanne, Switzerland.' Also, the applicable rules for the ad hoc divisions provide that their seats and panels are always in Lausanne, Switzerland. ${ }^{21}$ Furthermore, there is no impact on the seat of the arbitration, even if a case is administrated by one of the decentralised offices in Sydney or New York. Hence, regardless of any hearing in another place, the seat of the arbitral tribunal for all CAS cases is always in Lausanne, Switzerland.

<http://www.tas-cas.org/d2wfiles/document/1448/5048/0/award\%20Belinda\%20Van\%20Tienen.pdf> at 14 July 2008. However, sports like eg Rugby League (AFL) do not recognise the CAS jurisdiction.

15 Raguz v Sullivan [2000] NSWCA 240.

16 Damian Sturzaker and Kate Godhard, 'The Olympic Legal Legacy' [2001] Melb JIL 11 comment: 'The international and domestic laws applicable to disputes arising in international sporting events may not always be compatible. This case illustrates the tension that arises when international arbitral bodies, such as the CAS, attempt to make themselves immune from interference by domestic courts, which may themselves be vehemently opposed to any impediment to their sovereignty. The rules that govern disputes arising between competitors and their associations may be substantially different to the domestic rules applicable in the place where the sporting event is held. This is an important issue in an era when international sporting events such as the Olympic Games attract so much global attention and will undoubtedly be the source of a number of future disputes' $<$ http://www.austlii.edu.au/au/journals/MelbJIL/2001/11.html> at 22 October 2008.

17 Sometimes the procedural law of the arbitration is also called 'curial law' (Butterworths, above $\mathrm{n}$ 4, [7]).

18 Ibid; Alan Redfern, Martin Hunter, Nigel Blackaby and Constantine Partasides, Law and Practice of International Commercial Arbitration (4 $4^{\text {th }}$ ed, 2004) [2-05].

19 Other terms are also 'applicable law' and 'governing law' (see Redfern, Hunter, Blackaby and Partasides, above $n$ 18, [2-31]).

20 Butterworths, above n 4, [7].

21 See Article 7(1) of the Arbitration Rules of the Olympic Games, above n 10 and article 7(1) of the Arbitration Rules for the UEFA 2008 Final Round, above n 10. 


\section{B Chapter 12 PILA as lex arbitri}

If at least one of the parties at the time the arbitration agreement was concluded was neither domiciled nor habitually resident in Switzerland, chapter 12 PILA is the relevant lex arbitri. ${ }^{22}$ These provisions are mandatory, unless the parties have excluded their application in writing and agreed to the exclusive application of the cantonal rules of procedures concerning arbitration..$^{23}$ As known by the author, there has never been a CAS case in which the parties used this option. ${ }^{24}$ Furthermore, the cantonal rules of procedures concerning arbitration apply if both parties are domiciled or habitually resident in Switzerland. ${ }^{25}$

In most CAS cases, one of the parties is neither domiciled nor habitually resident in Switzerland. In all these cases, Chapter 12 PILA is the relevant lex arbitri. This article is confined to these provisions.

\section{Main features of Chapter 12 PILA}

The PILA was enacted on 18 December 1987 and has been in force since 1 January 1989. Unlike the Australian International Commercial Arbitration Act 1974 (Cth), Chapter 12 PILA has not been adopted from the UNCITRAL Model Law on International Commercial Arbitration (Model Law). ${ }^{26}$ Compared with the Model Law, Chapter 12 PILA with only 19 articles is a short international law on arbitration. It concentrates on the essential aspects. ${ }^{27}$ Furthermore, Chapter 12 PILA is based on a liberal concept. That means the private autonomy plays an important role in Chapter 12 PILA. In many respects it gives the parties the option to conclude their own rules. ${ }^{28}$

\section{An overview about Chapter 12 PILA}

Chapter 12 PILA deals with (i) the scope of application and the seat of the arbitral tribunal (article 176 PILA), (ii) the arbitrability (article 177 PILA), (iii) the arbitration agreement (article 178 PILA), (iv) the appointment of the arbitral tribunal and the challenge of arbitrators (articles 179 and 180 PILA), (v) the lis pendens (article 181 PILA), (vi) provisions about the procedures (articles 182-185 PILA), (vii) the jurisdiction (article 186 PILA), (viii) provisions about the decision on the merits (articles 187-189 PILA), (ix) the finality and appeal of the arbitral award (articles 190 and 191 PILA), (x) the waiver of appeal (article 192 PILA), (xi) the deposit and certificate of enforceability (article 193 PILA) and (xii) foreign arbitral awards (article 194 PILA).

The following explanations focus on the procedural provisions and the procedures for appeals against CAS awards to the Swiss Supreme Court.

\section{PROCEDURE}

Chapter 12 PILA articles 182 - 185 deal with the procedure of international arbitrations in Switzerland. Article 182 PILA contains the general rule, article 183 PILA deals with provisional and protective measures, article 184 PILA concerns taking of evidence and article 185 PILA deals with the further assistance by the judge.

22 Article 176(1) PILA.

23 Article 176(2) PILA.

24 See Anton Schnyder, 'Rechtsbehelfe gegen Entscheide des Court of Arbitration for Sport (CAS)' (2005) Causa Sport 353, 353 and Bernhard Berger and Franz Kellerhals, Internationale und interne Schiedsgerichtsbarkeit in der Schweiz (2006) [105].

25 See Danilo Hondo $v$ WADA and others (Swiss Supreme Court 4P.148/2006 dated 10 January 2007).

26 Schedule 2 International Arbitration Act 1974 (Cth).

27 Berger and Kellerhals, above n 23, [88].

28 Ibid [88-89]. 


\section{E The Code as the relevant rules of arbitration}

According to article 182(1) PILA, the parties may set forth the arbitration procedure either directly or by reference to existing rules of arbitration. Further, they may choose a procedural law of their choice. However, irrespective of the procedure chosen, the arbitral tribunal shall accord equal treatment to the parties and their right to be heard in an adversarial proceeding. ${ }^{29}$ These requirements have to be fulfilled independent of the chosen rules of arbitration. ${ }^{30}$ If an arbitral tribunal does not respect the equality of the parties or their right to be heard in an adversarial proceeding, the parties can appeal against the arbitral award to the Swiss Supreme Court. ${ }^{31}$

Pursuant to R27 Code, the procedural rules of the Code apply whenever the parties have agreed to refer a sports-related dispute to the CAS. Thus, the Code applies as the relevant rules of arbitration in all CAS cases. The special provisions applicable to the ordinary arbitration procedure (R38-R46 Code) and those applicable to the appeal arbitration procedure (R47-R59 Code) should ensure the CAS accords equal treatment to the parties and their right to be heard in an adversarial proceeding.

\section{F Provisional and protective measures}

Although the CAS procedure is fast, sometimes it is not fast enough to effectively protect the athlete's rights. In this case, the athlete has to request provisional or protective measures. ${ }^{32}$

According to article 183(1) PILA the arbitral tribunal may order provisional or protective measures at the request of one party, unless the parties have agreed otherwise. R37 Code explicitly permits the president of the relevant division or the panel to order provisional or protective measures. However, a party can only request provisional or protective measures from the CAS after the request for arbitration or the statement of appeal, which implies the exhaustion of internal remedies, has been filed with the CAS. ${ }^{33}$ Before that, the party has to request the competent judge to order provisional or protective measures. ${ }^{34}$

R37(2) Code contains an express waiver of the parties to request provisional or protective measures from state authorities in any disputes subject to appeal arbitration proceedings. ${ }^{35}$ In other words, after the statement of appeal has been validly filed with the CAS, the relevant CAS tribunal is the only competent authority to order provisional and protective measures. The Swiss jurisprudence basically recognises this exclusivity of the CAS tribunal. ${ }^{36}$ Nonetheless, this recognition of the CAS arbitral tribunal in Switzerland does not prevent foreign judges ordering provisional or protective

29 Article 182(3) PILA.

30 Frank Vischer, Art 182 in: Daniel Girsberger, Anton Heini, Max Keller, Jolanta Kren Kostkiewicz, Kurt Siehr, Frank Vischer und Paul Volken (ed), Kommentar zum Bundesgesetz über das Internationale Privatrecht (IPRG) vom 18. Dezember 1987 (Zürcher Kommentar) (2nd ed, 2004) [22].

31 Article 190(2)(d) PILA (see below I).

32 Antonio Rigozzi, 'Provisional Measures in CAS Arbitrations' in Blackshaw, Siekmann and Soek (ed) above n 2, 216-217; Fridolin Walther, 'Vorläufiger Rechtsschutz durch Schiedsgerichte' in Antonio Rigozzi and Michele Bernasconi (ed), The Proceedings before the Court of Arbitration for Sport (2007) 111, 111-112; Stephan Netzle, 'Die Praxis des Tribunal Arbitral du Sport (TAS) bei vorsorglichen Massnahmen' in Antonio Rigozzi and Michele Bernasconi (ed), The Proceedings before the Court of Arbitration for Sport (2007) 136, 136.

33 R37(1) Code.

34 Walther, above n 32, [123].

35 'This waiver does not apply to provisional or conservatory measures in connection with disputes subject to ordinary arbitration proceedings' (R37(2) Code last sentence).

36 Frank Vischer, Art 183 in: Girsberger, Heini, Keller, Kren Kostkiewicz, Siehr, Vischer und Volken (ed), above n 30, [3]; Rigozzi, above n 32, [221-222]; Walther, above n 32, [127]; Netzle, above n 32, [136] all with further references. To the knowledge of the author, there has been no Swiss case law on this matter. 
measures at party requests. For example, German and US courts have granted provisional and protective measures, even though the CAS appeal proceedings were pending. ${ }^{37}$

Unlike state courts, arbitral tribunals do not have the power to enforce provisional and protective measures. Nor does the CAS have the power to impose financial penalties in case of noncompliance with the provisional and protective measures. The parties have to respect the provisional and protective measures of the CAS voluntarily. ${ }^{38}$ Article 183(2) PILA gives the CAS the possibility to request the assistance of the relevant Swiss judge ${ }^{39}$ if the party concerned fails to submit voluntarily to the provisional and protective measures ordered. ${ }^{40}$

Finally, the CAS or the Swiss judge may condition the requested provisional or protective measures on the posting of an appropriate security. ${ }^{41}$

\section{G Taking of evidence}

According to Article 184(1) PILA the arbitral tribunal shall itself take evidence. The proceedings of taking of evidence by the arbitral tribunal depend on the applicable arbitration rules ${ }^{42}{ }^{43}$ Thus, in all CAS cases the procedural rules of the Code are relevant regarding the taking of evidence. For the ordinary arbitration procedure these are the rules of R44 Code and for the appeal arbitration procedure these are the rules of R51 and R55-57 Code.

Like every arbitral tribunal, the CAS can take evidence so long as the parties, the relevant witnesses, experts and third parties voluntarily accept the CAS's orders. If not, the CAS or, with the CAS's consent, a party may request the assistance of the judge at the District Court of Lausanne based on article 184(2) PILA. ${ }^{44}$

\section{H Further assistance by the judge}

Pursuant to article 185 PILA the judge at the District Court of Lausanne has jurisdiction if further assistance of the judicial or administrative authorities is required. Such further assistance is required e.g. for complaints regarding the delay of the arbitral procedure of for reliefs to repeat certain arbitral proceedings because an arbitrator was replaced. ${ }^{45}$

\section{APPEAL AGAINST CAS ARBITRAL AWARDS}

The provisions about the appeal against arbitral awards are shortly stated in Chapter 12 PILA. Article 190 PILA contains the general rule. Article 191 PILA concerns the appellate jurisdiction. Furthermore, article 192 PILA includes provisions about the waiver of appeal.

37 Rigozzi, above n 32, [222-4]; Netzle, above n 32, [136-8].

38 According to Netzle, above $\mathrm{n} 32,[142]$ the parties mostly submit voluntarily to the provisional and protective measures ordered by the CAS.

39 This is basically the Swiss judge who has jurisdiction to enforce the provisional and protective measures (Frank Vischer, above n 36, [9]).

40 Rigozzi, above n 32, [233]; Frank Vischer, above n 36, [7-9]; Berger and Kellerhals, above n 23, [1159].

41 Article 183(3) PILA. R37(4) Code repeats the CAS's power to condition provisional and protective measures upon the provision of security.

42 Article 182(1) and (2) PILA.

43 Paul Volken, Art 184 in: Girsberger, Heini, Keller, Kren Kostkiewicz, Siehr, Vischer und Volken (ed), above n 30, [2]; Berger and Kellerhals, above n 23, [1198].

44 Paul Volken, above n 43, [16-24].

45 Berger and Kellerhals, above n 23, [1114]. 


\section{Reasons for appeal}

According to article 190(1) PILA, the arbitral award shall be final upon being communicated. Appeals against arbitral awards are only possible based on the extremely narrow grounds listed in article 190(2) PILA. These grounds are similar to the grounds for refusal of article V New York Convention ${ }^{46}$ and article 34 Model Law. ${ }^{47}$

Under article 190(2) PILA, an award may be challenged only (a) if the sole arbitrator was designated or the arbitral tribunal was constituted in an irregular way, (b) if the arbitral tribunal wrongfully accepted or declined jurisdiction, (c) if the arbitral tribunal decided on points of dispute which were not submitted or left undecided prayers for relief which were submitted, (d) if the principle of equal treatment of the parties or the right to be heard was violated or, (e) if the award is incompatible with public policy. ${ }^{48}$ Interlocutory awards or decisions may be challenged only if they dispose of a party's defence that the arbitral tribunal was irregularly constituted or wrongly decided for or against its own jurisdiction. ${ }^{49}$

Until now, the case Guillermo Cañas v ATP Tour ${ }^{50}$ has been the only CAS award which has been challenged before the Swiss Supreme Court. ${ }^{51}$ The professional tennis player Guillermo Cañas was tested positive to the prohibited substance hydrochlorothiazide (HCT). The ATP Anti-Doping Tribunal found that Guillermo Cañas had committed a doping offence under the ATP Rules, and imposed a two-year ban on him. ${ }^{52}$ Guillermo Cañas appealed against this decision to the CAS. He mainly argued that the HCT was in his body without his intention. Moreover, the decision of the ATP Anti-Doping Tribunal would contravene the law of Delaware and European and American laws regarding restraint of trade. The CAS reduced Guillermo Cañas' ban from 2 years to 15 months because his offence was not significant. The CAS award contained no considerations about Guillermo Cañas' argument that the decision of the ATP Anti-Doping Tribunal would contravene the law of Delaware. ${ }^{53}$ The Swiss Supreme Court admitted Guillermo Cañas' appeal against the CAS award because this award included no considerations about the law of Delaware, although Guillermo Cañas expressly alleged in his submissions that the decision of the ATP Anti-Doping Tribunal would violate this law regarding restraint of trade. The lack of any considerations about the law Delaware contravened the right to be heard (article 190(2)(d) PILA). This right demands that the court or the arbitral tribunal deal with all arguments alleged by the parties. ${ }^{54}$

46 United Nations Conference on International Commercial Arbitration Convention on the Recognition and Enforcement of Foreign Arbitral Awards 1958 (see schedule 1 International Arbitration Act 1974 (Cth)).

47 Berger and Kellerhals, above n 23, [1543].

48 Gabrielle Kaufmann-Kohler and Philippe Bärtsch, 'The Ordinary Arbitration Procedure of the Court of Arbitration for Sport' in Blackshaw, Siekmann and Soek (eds), above n 2, [69, 94].

49 Article 190(3) PILA; Kaufmann-Kohler and Bärtsch, above n 48, [94].

50 Decision of the Swiss Supreme Court 4P.172/2006 dated 22 March 2007, published under the official collection number 133 III $235<$ http://www.bger.ch/index/juridiction/jurisdiction-inherittemplate/jurisdiction-recht/jurisdiction-recht-leitentscheide1954.htm> at 4 July 2008.

51 Christoph Brunner, 'Rechtsmittelverzicht in der internationalen Schiedsgerichtsbarkeit: eine Standortbestimmung nach dem Cañas-Urteil (BGE 133 III 235 )’ (2008) AJP/PJA 738, 738; Frank Oschütz, 'Bundesgericht hebt erstmals Schiedsspruch des CAS/TAS auf' (2007) Jusletter of 4 June 2007 [1], <http://www.weblaw.ch/de/content_edition/jusletter/artikel.asp?ArticleNr=5698\&lang=de> at 7 July 2008.

52 Guillermo Cañas v ATP Tour <http://www.itftennis.com/shared/medialibrary/pdf/original/IO_17684_original.PDF> at 22 October 2008.

53 CAS2005/A/951 Cañas v/ATP dated 23 May 2006 <http://www.itftennis.com/shared/medialibrary/pdf/original/IO_20386_original.PDF> at 22 October 2008.

54 BGE 133 III 235 E. 5.2. 


\section{THE CAS - ARBITRAL INSTITUTION WITH ITS SEAT IN SWITZERLAND}

\section{J Swiss Supreme Court as the only appellate instance}

According to article 191 PILA, the Swiss Supreme Court shall be the sole appellate forum for arbitral awards. In Raguz $v$ Sullivan ${ }^{55}$, the only remedy for Rebecca Sullivan to challenge the CAS award would have been an appeal to the Swiss Supreme Court.

The appeal procedure shall be governed by article 77 Federal Supreme Court Act 2005 (FSCA) ${ }^{56}$. It is called an appeal in civil matters. ${ }^{57}$ The subsidiary appeal in constitution matters does not apply for arbitral awards. ${ }^{58}$ According to this appeal procedure, the request for appeal has to lodge with the Swiss Supreme Court within 30 days from the notification of the award. ${ }^{59}$ Only registered attorneys can represent the parties in appeals before the Swiss Supreme Court. ${ }^{60}$

\section{K Waiver of appeal}

According to article 192(1) PILA, the parties may completely or partially exclude any challenge to the arbitral award by an explicit declaration in the arbitration agreement, or in a subsequent written agreement if no party has its domicile, ordinary residence or a business establishment in Switzerland. The Swiss Supreme Court demands that the exclusion declaration be singular and clear. A reference to incorporate a further document which contains an exclusion declaration is not possible. ${ }^{61}$

The rules of R46(2) and R59(2) Code are in line with article 192(1) PILA. ${ }^{62}$ After these rules the award notified by the CAS Court Office,

may not be challenged by way of an action for setting aside to the extent that the parties have no domicile, habitual residence, or business establishment in Switzerland and that they have expressly excluded all setting aside proceedings in the arbitration agreement or in an agreement entered into subsequently, in particular at the outset of the arbitration.

In Guillermo Cañas v ATP Tour63, Guillermo Cañas signed a consent and agreement to the ATP Official Rulebook which stated, '[t]he decisions of CAS shall be final, non-reviewable, nonappealable and enforceable'. ${ }^{64}$ But the Swiss Supreme Court decided that article 192(1) PILA

55 Raguz v Sullivan [2000] NSWCA 240.

56 Federal Supreme Court Act 2005 <http://www.admin.ch/ch/d/sr/1/173.110.de.pdf> at 22 October 2008.

57 Hans Peter Walter, 'Rechtsmittel gegen Entscheide des TAS nach dem neuen Bundesgesetz über das Bundesgericht und dem Entwurf einer Schweizerischen Zivilprozessordnung' in Rigozzi and Bernasconi, above n 32, [155, 167]; Berger and Kellerhals, above n 23, [1622].

58 Ibid.

59 Article 100(1) FSCA. After the expiry of this 30-day deadline, the only possibility to challenge a CAS award is to file a so called application for revision. This remedy may only be brought on very limited grounds (see Kaufmann-Kohler and Bärtsch, above n 48, [95] as well as Berger and Kellerhals, above n 23, [17851817]).

60 Article 40(1) FSCA.

61 BGE 133 III 235 E. 4.3.1; BGE 131 III 173; Oschütz, above n 51, [6]. For further information see Berger and Kellerhals, above n 23, [1676-1681] as well as Brunner, above n 51, [743-748].

62 Kaufmann-Kohler and Bärtsch, above n 48, [94].

63 BGE 133 III 235.

64 'PLAYER'S CONSENT AND AGREEMENT TO ATP OFFICIAL RULEBOOK

$I$, the undersigned player, consent and agree as follows:

1. I consent and agree to comply with and be bound by all of the provisions of the 2005 ATP Official Rulebook ('the ATP Rules'), including, but not limited to, all amendments to the ATP Rules and all the provisions of the AntiDoping Program incorporated in the ATP Rules. I acknowledge that I have received and had an opportunity to review the ATP Rules.

2. I also consent and agree that any dispute arising out of any decision made by the Anti-Doping Tribunal, or any dispute arising under or in connection with the Anti-Doping Program, after exhaustion of the Anti-Doping 
basically does not apply to sports arbitrations' verdicts. These verdicts mostly consist of banning the sportspersons from competition. There is no examination of the arbitral award by a court during the recognition and the enforcement of the arbitral award. ${ }^{65}$ Furthermore, the sports federations have stronger negotiation powers than the sportspersons. The latter regularly have to accept the rules of the sports federations (including waivers of appeal) if they want to participate in the sports federations' competitions and events. According to these statements of the Swiss Supreme Court, most waivers of appeal are basically void regarding sports arbitrations' verdicts. ${ }^{66}$

Program's Anti-Doping Tribunal process and any other proceedings expressly provided for in the Program, shall be submitted exclusively to the Appeals Arbitration Division of the Court of Arbitration for Sport ('CAS') for final and binding arbitration in accordance with the Code of Sports-Related Arbitration. The decisions of CAS shall be final, non-reviewable, non-appealable and enforceable. I agree that I will not bring any claim, arbitration, lawsuit or litigation in any other court or tribunal. The time limit for any submission to CAS shall be 21 days after the decision of the Anti-Doping Tribunal has been communicated to me.

3. I have read and understand the foregoing Player's Consent and Agreement.' (BGE 133 III 235).

65 See article V New York Convention.

66 Oschütz, above n 51, [11-12]; Brunner, above n 51, [748-749]. 